\title{
SELF-DEFENSE AS A NON-JURISDICTIONAL FORM OF PROTECTION OF THE RIGHTS OF INTERNALLY DISPLACED PERSONS IN UKRAINE
}

\author{
Teremetskyi Vladyslav ${ }^{1}$ \\ Batryn Olesia ${ }^{2}$
}

DOI: https://doi.org/10.30525/978-9934-571-89-3_61

As we know, the jurisdictional form of protection is the most widespread in the field of protecting property rights of internally displaced persons, since it includes judicial, administrative and notarial defense procedure. However, there is also a nonjurisdictional form of protection of the rights of these individuals. To determine its specific features, it is first necessary to characterize non-jurisdictional form of protection of subjective rights within civil law of Ukraine.

Part 5 of the Art. 55 of the Constitution of Ukraine contains the rule according to which everyone has the right to protect the rights and freedoms from violations and unlawful encroachments by any means not prohibited by the law [1]. This norm is reflected in the Section 3 of the Civil Code of Ukraine. Thus, according to Part 1 of the Art. 15 of the Civil Code of Ukraine, each person has the right to protect his civil right in case of its violation, non-recognition or disputes, Part 1 of the Art. 20 of the Civil Code of Ukraine establishes the principle of exercising the right of a person to protect, and the Art. 19 of the Civil Code of Ukraine establishes the concepts and methods of self-defense of civil rights [2]. This indicates that any person has the

\footnotetext{
${ }^{1}$ Ternopil National Economic University, Ukraine

${ }^{2}$ Judge of Pecherskyi District Court of Kyiv, Ukraine
} 
opportunity to independently apply certain forms of protection of his / her right, in particular non-jurisdictional one.

O.P. Serhieieva rightly points out that non-jurisdictional form of protection covers the actions of citizens and organizations in protecting civil rights and interests that they exercise independently, without addressing to state or competent authorities. These actions are united into the concept of "self-defense of civil rights" in the Civil Code of Ukraine [3, p. 284].

The common feature of the views expressed in the scientific literature on the essence of self-defense is the desire of scholars to reduce the use of self-defense by pointing to a certain range of civil legal relations or otherwise, giving it the character of an exceptional measure. The main difference between the views of scholars is to determine the object of self-defense and legal qualification of its content (actions of the person concerned). Self-defense as the method of protecting civil rights is characterized by the fact that a person protects his civil rights and interests independently, by his own actions. It is protection without addressing to the court or other state agency that protects civil law.

Urgent and important issues of protecting the rights and interests of internally displaced persons, namely the self-defense method, include Guiding Principles on Internal Displacement. Thus, Section III ("Principles Relating to Protection During Displacement") is aimed at resolving issues related to the violation of the rights of internally displaced persons, including property ones. Principle 21 states that no one shall be arbitrarily deprived of property and possessions. Paragraph 2 of the same principle contains the provision that the property and possessions of internally displaced persons shall in all circumstances be protected, in particular, against the following acts: pillage; direct or indiscriminate attacks or other acts of violence; being used to shield military operations or objectives; being made the object of reprisal; and being destroyed or appropriated as a form of collective punishment [4]. Although this collection of rules is not a regulatory document in its direct meaning, however, after the adoption of the resolution of the UN Commission on Human Rights (1998) it was emphasized that the Special Representative of the SecretaryGeneral of the United Nations on internal displacement issues will rely on them in the framework of the dialogue with governments and all those whose mandates or activities relate to internal displacement. Thus, taking into account the world's standards of ensuring and keeping human rights in our state and the European, democratic vector for the development of socio-political processes in Ukraine, we can state that we must adhere to international human rights standards. At the same time, providing such rights as property right, the right to return to their homes (when it comes to internally displaced persons), the right to protection from forced internal displacement, etc. at the state level, Ukraine guarantees to internally displaced persons the observance of these rights. When it comes to guarantees, this indicates that these rights can be protected in case of violation. And in this case self-defense can not be an exception.

The Art. 1 of the Law of Ukraine "On Ensuring the Rights and Freedoms of Internally Displaced Persons" dated from October 20, 2014 No. 1706-VII, defining 
the concept of internally displaced persons, considers both Ukrainian citizens and foreigners and stateless persons [5], who according to the Art. 26 of the Constitution of Ukraine enjoy the same rights and freedoms, as well as have the same responsibilities as citizens of Ukraine [1].

The above indicates that internally displaced persons may use all means permitted by the law to defend their violated rights. However, in the course of self-defense, actions committed by such persons must be commensurate with the caused damage. For example, in order to protect their own home, such persons may install additional housing protection measures (alarm system, grilles on windows, etc.) or take socalled preventive measures.

Sometimes there is a situation where, in the case of forced internal movement or forced return to the abandoned place of residence, a person does not agree with such actions and, having the right to self-defense, evades the execution of the measures of coercive nature against him. This human right is stated in the Art. 3 of the Law of Ukraine "On Ensuring the Rights and Freedoms of Internally Displaced Persons" [5]. However, by establishing this rule, the law does not indicate how exactly a person can protect his or her right. Therefore, it can be assumed that it is done by avoiding certain actions that are not independent non-jurisdictional way of protecting property rights of internally displaced persons, but serves only as a kind of possible variants of a person's behavior while self-defense.

Despite the wide range of the rights of internally displaced persons and the ways of their protection, some scholars believe that it is not enough to commit only an independent action for a person to defend his right. For example, Yu.H. Basina and A.H. Didenko state that self-defense is considered not only the actions of the authorized person, directly addressed to the offender, but also actions performed on his request by other persons (agencies), who do not consider the dispute between the parties [6, p. 8]. An example of this is the Pinheiro principles, which state that everyone should be able to submit a claim for restitution and / or compensation to an independent and impartial body (Principle 13.1). The right to full and effective compensation is an integral part of the restitution process. Compensation may be monetary or in kind, when the remedy of restitution is not factually possible, or when the injured party knowingly and voluntarily accepts compensation in lieu of restitution, or when the terms of a negotiated peace settlement provide for a combination of restitution and compensation. (Principle 21.1) [7]. However, we do not agree with the opinion of these scholars, because restitution is a jurisdictional form of protection, which in essence provides a mechanism of a person's appeal to a competent authority for the protection of his violated right.

Thus, self-defense is the most operational and effective form of protecting civil rights and interests, which becomes vital in the relations involving internally displaced persons, since such relationships require a quick and clear response. Unfortunately, the legislator, at the present stage of development of the legal system, defines self-defense only in general terms, without detailing it and not revealing the legal possibilities of individuals to protect their rights in relation to specific situations. Of course, it also refers to situations involving internally displaced 
persons. Therefore, one can assume that the realization of self-defense of property rights of internally displaced persons will consist in the commission of adequate, within the limits of law, actions by a person whose right is violated for restoration or elimination of negative factors influencing it.

On the other hand, the jurisdictional form of protection of violated rights includes the possibility of an individual to appeal to the competent authorities with the requirement to restore the right. In case of internally displaced persons, the feature of this procedure will differ only in the fact that not all state authorities have the power to consider the issue of protecting the rights of internally displaced persons. Such issues fall within the competence of specially created agencies and authorities competent to deal with such issues.

As a conclusion, we note that today in Ukraine there is almost no nation-wide concept of protecting and restoring property rights of forced migrants. However, the national regulatory base contains separate provisions, the use of which allow the protection of certain rights of internally displaced persons. Therefore, by improving the Ukrainian legislation in this context, it is necessary to actively use the world experience and standards of the Council of Europe. However, by borrowing certain norms of foreign law we should address the problem issues of protecting the rights of internally displaced persons, taking into account the current realities and existing challenges of Ukrainian society.

\section{References:}

1. Konstytutsiia Ukrainy [The Constitution of Ukraine]. Zakon Ukrainy No. $254 \mathrm{~K} / 96-\mathrm{BP}$ (28 June, 1996). Retrieved from: https://zakon.rada.gov.ua/laws/show/254\%D0\%BA/96$\%$ D0\%B2\%D1\%80 (accessed 20 February 2019).

2. Tsyvilnyi kodeks Ukrainy [The Civil Code of Ukraine]. Zakon Ukrainy No.435-IV (16 January, 2003). Retrieved from: https://zakon.rada.gov.ua/laws/show/435-15 (accessed 21 February 2019).

3. Grazhdanskoe pravo [Civil law] (1999). Uchebnik. Ch. I. Idanie 3. pod red. A.P. Sergeeva, Yu.K. Tolstogo. M.: Prospekt. (in Russian)

4. UN Documents. Gathering a body of global agreements. Annex. Guiding Principles on Internal Displacement (11 February, 1998). Retrieved from: http://unhcr.ru/dokumenty.html (accessed 21 February 2019).

5. Pro zabezpechennia prav i svobod vnutrishno peremishchenykh osib [On Ensuring The Rights And Freedoms Of Internally Displaced Persons]. Zakon Ukrainy No. 1706-VII (20 October, 2014). Retrieved from: https://zakon.rada.gov.ua/laws/show/1706-18 (accessed 20 February 2019).

6. Basin Yu.G., Didenko A.G. Zashchita subieektivnykh grazhdanskikh prav [Protection of civil rights]. Alma-Ata: Izd-vo Kaz. un-ta. (in Kazakhstan)

7. Centre on Housing Rights and Evictions. The Pinheiro Principles. United Nations Principles on Housing and Property Restitution for Refugees and Displaced Persons (2005). Retrieved from: https://2001-2009.state.gov/documents/organization/99774.pdf. 